\title{
Determinants of Cost of Fund In Indonesia Government Banks
}

\author{
Nurshadrina Kartika Sari \\ STIE Mandala Jember \\ Jember, Indonesia \\ shadrina.kartika@stie-mandala.ac.id
}

\author{
Nanda Widaninggar \\ STIE Mandala Jember \\ Jember, Indonesia \\ nandwieda@stie-mandala.ac.id
}

\begin{abstract}
This research aims to provide empirical evidence about the contribution of asymmetric information, institutional ownership, bank size and earning management to cost of fund. This research was conducted using a population of Indonesia Government Banks period 2010 until 2016. Samples was selected based in the following criteria do not do corporate action such as merger and acquisition. Data analysis was conducted for four of Indonesia Government Banks. The results provide empirical evidence that: (1) Asymmetric Information, Institutional Ownership and Bank Size did not have contribution to Earning Management, (2) Earning management did not have contribution to Cost of Fund. The implication of this research is the mechanism of cost of fund in Indonesia Government Banks are strongly affected by the economic stabilization, interbank competition and bank efficiency in using IT.
\end{abstract}

Keywords-Cost of Fund; Banking; Government Bank; Earning Management.

\section{INTRODUCTION}

Bank as financial institution are reguled by government regulations. Based on Indonesia Bank Regulation numbers 10 of 1998, one of the duties of the bank are collect and distribute the funds from the public [1]. Bank need to achive market efficiency so there are not asymmetric information between bank and the funder/investor. Financial statement is used for the funder to evaluate the bank performance. Earning always the center point for the investor to ensure that manager have run their role.

The size of the banks can be seen from the total assets, banks that have a large asset are the government banks. The largest shareholding of a Government Bank owned by the Government of Republic of Indonesia, it is $60 \%$ of the total outstanding shares. With the existence of institutional ownership can serve as monitoring agent. The size of the larger banks can increase the complexity of the information; this will provide management opportunities to do earnings management practice.

Bank transparency in financial reporting has been regulated in Otoritas Jasa Keuangan (OJK) Regulation Number 32 of 2016, since disclosure in the financial statements is considered important to maintain customer trust [2]. Third Party Fund (DPK) is the largest source of funding owned by banks; therefore banks need to develop a funding strategy that can balance the funding needs and the distribution of these funds later. Failure in determining funding will affect the bank's liquidity.

In addition to maintaining liquidity, bank also need to take into account the cost of funds to be paid later on funds entrusted to customers. Both come from third party funds and shares traded on the securities market.

The cost of funds increases if the funds collected by the bank are sourced from funds at high cost, this can happen if the customer assesses the risks arising from information submitted by the bank. Submission of financial information is critical to improving customer trust in the bank, while the practice of earnings management itself is still considered less open in reporting its performance due to certain motives.

This study was conducted to obtain empirical answers to the contribution of asymmetric information, institutional ownership and bank size to earnings management and earning management contribution to the cost of funds at Government Banks in Indonesia.

\section{THE ANTECEDENT OF EARNING MANAGEMENT}

Earning management began to be introduced by Watts and Zimmerman in 1978, they found that manager's behavior to manipulate their earning was to maximize the value of the company [3].

Akerlof in 1970 is the first one to come up with the concept of asymmetric information between agent and principal [4], through from this theory we know the reason manager get the opportunity to do earning manipulation. And also because of the agency theory that explain about the differences the goals between agent and principal [5].

Earning management can not be interpreted as a negative action since it does not solely concern with earning manipulation [6]. Based on the previous research about earning management through in some evidence in different country, asymmetric information, ownership structure, business risk, size of company, corporate governance, are the factors that effect on earning management [7];[8];[9];[10];[11]. 
In banking sector the practice of earning management also find in some research, and bank have a different regulation and characteristic of business. Bank use earning management aggressively during the financial crisis to cover their bank's perfomance [12]. Loan loss provisions is used for earning management practice by the manager, this indicates that the reported earnings may not reflect the true economic reality [13]. Dong, Liu and Hu (2012) provides evidence for relation of bank loan loss provisions and capital adequacy ratio in China's comercial banks [14].

Bank need to take care of their capital adequacy ratio (CAR) to obey the government regulation. Besides that bank also need to increase their profitability and show bank in good performance. Bank use loan loss provision (LLP) as tool of earning management, but use LLP will give some long term impact. Increasing LLP would improve the bank's CAR but would also cause reported earning to be lower, this will decrease investor perception on bank performance [13].

Earning management cause higher risk for bank, the income smoothing effect can help managers to meet expectations, but expose banks to higher future risks [15]. If investor find the hidden risk it will cause higher return for their funding. Bank will pay high cost of fund to their investor, and it will reduce their profit.

The study of cost of fund have started by Watson in 1978 when the management of Franklin National Bank fail to estimated bank cost of fund, historical average cost could not able to give the right estimation for the bank to assessed cost of fund that must paid. From that study there was the method for estimated cost of fund, marginal cost [16]. Capital structure was selected by bank also effected the cost of fund.

Bank cost of fund is reflected by competitive loan market, the loan interest rate that charged to the borrower and the risk characteristics of borrower [17]. Official Cash Rate (OCR) as regulatory changes had impact for cost of funding banks. Banks can found stable sources of funding during the crisis because of the OCR [18].

The credit worthiness institution, return of market value and level and quality of capital [19], reflected the change of funding cost in bank. Funding cost affected for monetary and financial stability [20].

It is important to bank to use cost of fund because of the ability to increase profit and protect the bank health. That's why as the decision maker, manager must do their important role to keep the bank perform. Earning management affected cost of fund bank and manager used their ability to manipulate earning through of marginal cost of debt. It shows that bank must equalize their present benefits and their future costs [21].

\section{PLATFORM DESIGN IDEAS}

\section{A. The contribution of asymmetic information to earning management}

Bank management earn authority from shareholder to manage the bank, if they manage well the bank so they can increase their profit. Profitability is one of the indicator to asesss management performance. In other side manager have their desire to optimization their wealthy. When there is an asymmetric information between manager and principal, it will be a gap for manager to do earning management. High asymmetric information in the company will make manager do earning management aggressively [22].

\section{B. The contribution of institutional ownership to earning management}

Institutional ownership of government banksare the highest one in Asia, it make disruption of inefficiency market. It can be monitoring agents at the bank, which may lead to reduce earning management practice. Majority shareholder in crisis Korea make them aware of earning management practice [23]. Consistent with the research, Greco explain that increasing of institutional ownership participation can be the monitoring tool for earning management [24].

\section{The contribution of bank size to earning management}

Government banks have largest asset among Indonesian commercial banks, it cause conflict of interest from government intervention of bank decisions. The allocation of bank asset is closely related of bank liquidity which the substantial portion of assets allocated as credit loans.

Earnings maximization is a demand that must be fulfilled by management, either for stakeholders, shareholder, customers, depositors or the public. Profit becomes a performance indicator of the bank, thus forcing management to be able to optimize the fund it hasand to complying with the regulations from the Central Bank.

\section{The contribution of earning management to cost of fund}

Bank as financial institution which based on the trust of their customers, that's why bank must be measured by using the CAR as the regulation for bank health. Based on Bank Indonesia's regulation number 14/18/PBI/2012bank must have $8 \%$ minimum of their CAR [25].

The calculation of cost of fund is important because it is used as one of the considerations for bank to determining the interest rate. The lower of interest rate which paid to the customer, the chance for bank in optimizing the effectiveness of its business will be higher. Bank management use earning management not only to show a good performance but also to fulfil stakeholders expectation [21]. 


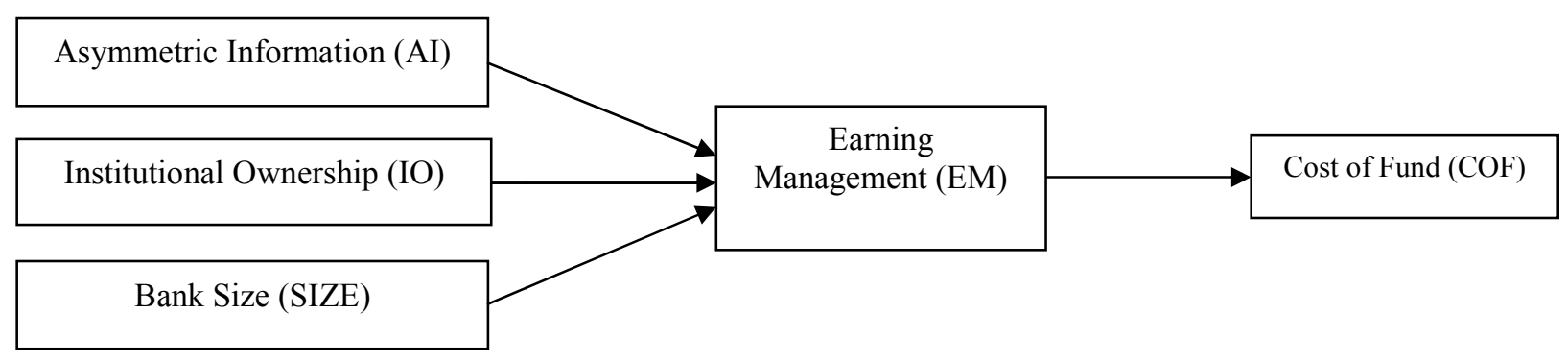

Fig. 1 Platform design ideas

Fig. 1 displays this platform design ideas of this research, we want to know the contribution of asymmetric information, institutional ownership and size of bank to earning management and also want to know the contributrion of earning management to cost of fund. This research use regretion model to answer that quetions.

\section{THE CONTENTS OF PLATFORM CONSTRUCTION}

\section{A. The Sample}

The sample of this research are four Indonesia government banks in period 2010 until 2016. The criteria proposed by researcher are Indonesia government banks, who did not do corporate actionare mergers and acquisitions during the observation period 2010 to 2016 .

\section{B. Construct Regression Model}

TABLE 1. REGRESSION MODEL 1

\begin{tabular}{|cc|r|r|r|r|r|}
\hline & & \multicolumn{2}{|c|}{$\begin{array}{c}\text { Unstandardized } \\
\text { Coefficients }\end{array}$} & $\begin{array}{c}\text { Standardized } \\
\text { Coefficients }\end{array}$ & & \\
\cline { 3 - 4 } & Model & \multicolumn{1}{|c|}{$\boldsymbol{B}$} & Std. Error & \multicolumn{1}{c|}{ Beta } & \multicolumn{1}{c|}{$\boldsymbol{t}$} & Sig. \\
\hline \multirow{2}{*}{1} & (Constant) & $-7,879$ & 3,686 & & $-2,137$ & 0,122 \\
& AI & $-0,022$ & 0,025 & $-0,288$ & $-0,870$ & 0,448 \\
& IO & 0,010 & 0,005 & 1,072 & 1,919 & 0,151 \\
& SIZE & 0,165 & 0,074 & 1,165 & 2,222 & 0,113 \\
\hline
\end{tabular}

Based on Tab. 1, regression model 1 this research is $\mathrm{EM}=-7,879-0,022 \mathrm{IA}+0,010 \mathrm{KI}+0,165 \mathrm{SIZE}$

TABLE 2. REGRESSION MODEL 2

\begin{tabular}{|cc|r|r|c|c|c|}
\hline & & \multicolumn{2}{|c|}{$\begin{array}{c}\text { Unstandardized } \\
\text { Coefficients }\end{array}$} & $\begin{array}{c}\text { Standardized } \\
\text { Coefficients }\end{array}$ & & \\
\cline { 3 - 5 } & Model & \multicolumn{1}{|c|}{ B } & Std. Error & Beta & \multicolumn{1}{c|}{$\boldsymbol{t}$} & Sig. \\
\hline 1 & (Constant) & $-4,497$ & 0,143 & & $-31,344$ & 0,000 \\
& EM & 0,123 & 0,567 & 0,096 & 0,217 & 0,837 \\
\hline
\end{tabular}

And based on Tab. 2, regression model 2 of this research is $\mathrm{COF}=-4,497+0,123 \mathrm{EM}$

\section{Discussion of contribution of asymmetric information to earning management}

Indonesia government banks are one of financial institution who regulated by the government. They must show and inform their performance to the public and stakeholder with transparency and accountability as a form of implementation of good corporate governance (GCG). In theory, the disclosure of information by the management can be the signals to suppress the practice of earning management by the company, but in Indonesia government bank the opposite thing happened. There is no contribution of asymmetric information to earning management.

The overall economy of Indonesia during 2010 until 2016 was in good condition, it showed by the inflation can be held according to the government target and the Rupiah exchange rate also tend to be stable, it also felt especially for banking sector. Although the overall performance of bank has increased as the impact of a stable economy and Third Party Fund (DPK) that can be collected by Indonesia government banks increased, but the growth of credit is still low. The BI Rate that is expected to reduce the interest rate of lending rate it has not been able to become a reference of commercial bank in Indonesia, because they are still pegged on the FED.

Global economic considerations that are still unstable and the number of foreign funds invested in Indonesia government banks force management to implement various policies to show good performance as the public and stakeholders expectation.

\section{Discussion of contribution of institutional ownership to earning management}

The shareholding of Indonesia government banks, were originally intended for economic and social purposes. Market competition becomes unbalanced due to government intervention in Indonesia government banks. The performances of the banks were not optimal and since the crisis in 1997 the commercial bank lost public trust and caused declining of bank performance.

To improve the performance bank, the government sold some shares to the public including to foreign investors. The impact of this privatization is the bank becomes more competitive and able to reduce the centralization of ownership by one particular party. Not only do privatization, some banks must also be merged or acquired by the other banks, including Mandiri Bank. Merger companies do earning management two 
years during the companies merged until three to five years after merger. The declining shareholding by the government does not increase or decrease the earning management action; this is because the Indonesia government with Bank Indonesia makes a same regulation for all commercial bank. Indonesia government banks must maintaintheir performance and public trust.

\section{E. Discussion of contribution of bank size to earning management}

Bank size is measured by total all the assets bank.Among commercial banks in Indonesia, Indonesia government banks have considerable assets. One of them is Bank Mandiri as the bank with largest asset in Indonesia. The complexity of information in large companyhigher, this result of this study indicate that bank size has no effect on earning management practices.

Companies with large size tend to be public concerns rather than small companies; this encourages companies to apply better quality of GCG [26]. Likewise with Indonesia government banks since the share owned by public, they must apply GCG and increase public trusted. One of the function of GCG is balancing the authority between stakeholders and shareholders including Directors and Managers in controlling and limiting the emergence of faulty management of corporate resources and misuse of assets. With good transparency and accountability, the corporate culture will lead to awareness of good behavior as a form of corporate responsibility to stakeholders and the public.

\section{F. Discussion of contribution of earning management to cost of fund}

The existence of IFRS implementation also reduces the opportunity for management in earnings management [27]. The earnings management behavior undertaken by management can be through higher LLP [28] in the assessment element and through the recognition of the realization time of the advantages and disadvantages of the securities [29]. With increasingly stringent rules in financial instruments that are also required by OJK in OJK regulation number 32 of 2016 concerning bank liabilities in transparency and publication of bank statements, limits earnings management behavior.

Earnings management has not been proven to contribute to the determination of COF in Indonesia government banks. The banking costumers do not consider earnings management as a consideration in the amount of income on the funds they entrust to the bank. The amount of COF that the bank must pay to the customers is influenced by the interest rate paid, the portfolio composition of the fund source, the mandatory minimum reserve requirement, the service cost, the tax on interest and the level of efficiency [30].

Factors that must be considered by banks in optimizing profits through the determination of interest rates both for lending and funding are factors of profitability, liquidity and risk [31]. The funding source of Indonesia government banks are still dominated by Third Party Funds (DPK), so the banks must be able to provide the best offer to be able to attract new customers and also retain old customers. The calculation of cost of funds will assist banks in determining the Basic Interest Rate of Credit (SBDK), therefore the bank is also required to be more efficient in conducting its operational activities.

\section{CONCLUSION}

Firstly, there are no contribution of asymmetric information, institutional ownership and bank size to earning management in Indonesia government banks during 2010 to 2016. The economic stabilization and the regulation from government with Bank Indonesia can increased the bank transparency and accountability.

Secondly, there is no contribution of earning management to cost of fund in Indonesia government banks during 2010 to 2016. One of the factors used in determination of cost of fund is the level of efficiency. Bank can reach the level of efficiency by optimization of IT.

\section{ACKNOWLEDGMENT}

This work was supported by The Ministry of Education Indonesia (KEMENRISTEK DIKTI) with research contract number 120/SP2H/LT/DRPM/IV/2017 on 3 April 2017.

\section{REFERENCES}

[1] I. Republic, Indonesia Constitution Number 10 of 1998. .

[2] Otoritas Jasa Keuangan (OJK), "Regulation number 32 of 2016 about Perubahan atas peraturan otoritas jasa keuangan nomor 06/POJK," in 03/2015 tentang transparansi dan publikasi laporan bank.

[3] and Z. J. L. Watts, R. L, "Toward a positive theory of the derermination of accounting standarts," Account. Rev., pp. 112-134, 1978.

[4] G. A. Akerlof, 'The Market for 'lemons': Quality uncertainty and the market mechanism," Q. J. Econ., vol. 90, no. 4, pp. 599-617, 1977.

[5] and F. R. and P. P. Mitnick, Barry M, "The theory of agency and some consequences," p. 2, 1973.

[6] T. A. Gumanti, "Earning Management: Suatu Telaah Pustaka," J. Akunt. Keuang., vol. 2, pp. 104-115, 2000.

[7] B. Bon, Joeng Kim and Sohn, "Real Earning Management and Cost of Capital," J. Account. Public Policy, p. 2013.

[8] H. Farooq, Omar and El Jai, “Ownership structure and earning management: Evidence from the casablanca stock exchange," 2012. [Online]. Available: http:/works.bepress.com/omar_farooq/19.

[9] D. D. Sari, Nurshadrina Kartika and Astuti, "Faktor yang mempengaruhi manajemen laba pada sektor perbankkan di Indonesia," J. Bus. Bank., vol. 5, no. 1, 2015. 
[10] Rezaei, "Efficent or opportunistic earnings management with regads to the role of firm size and corporate governance practices," vol. 3, no. 9, pp. 1312-1322, 2012.

[11] M. Abed, Suzan., Al-Attar, Ali and Suwaidan, "Corporate governance and earnings management: Jordanian evidence," Int. Bus. Res., vol. 5, no. 1, pp. 216-225, 2012.

[12] al Cohen, Lee et, Bank earnings management and tail risk during the financial crisis. unpublised, 2011.

[13] C. Anandarajan, Asokan., Hasan, Iftekhar and McCarthy, The use of loan loss provisions for earnings, capital management and signalling by australian banks. press, 2005.

[14] B. Dong, Xianlei., Liu, Jia and Hu, "Research on the relationship of comercial bank's loan loss provision and earning management and capital management," $J$. Serv. Sci. Manag., vol. 5, pp. 171-179, 2012.

[15] A. Beltrame, Federico., Previtali, Daniele and Sclip, Does earning management affect banks' cost of funding? An empirical investigation across an european sample. 2016.

[16] R. D. Watson, Estimating the cost of your bank's funds. 1978.

[17] D. N. Hubbard, R. Glenn., Kuttner, Kenneth N and Palia, Are there bank effect in borrowers' cost of funds? Evidence from a matched sample borrowers and banks. 1999.

[18] J. Wong, "Bank funding - the change in composition and pricing," Reserv. Bank New Zeal. Bull., vol. 75, no. 2, pp. 15-24, 2012.

[19] M. Babihuga, Rita and Spaltro, "Bank funding costs for international banks," 2014.

[20] E. et al. Beau, Bank funding costs: what are they, what determinaes them and why do they matter. 2014.

[21] S. C. et al. Valverde, Bank funding, financial instruments and decision-making in the banking industry. 2016.
[22] S. and C. Chi, The information asymmetry for the influence of earnings management on the long-run performance: Evidence from the issuance of convertible debt. National Cheng Kun University, 2001.

[23] Y. and W. Goh, "Majority shareholder ownership and real earnings management: a korean perspective," press, 2012.

[24] Groce, Ownership structure, corporate governance and earnings management in the European oil industry. 2012.

[25] Bank Indonesia regulation, "PBI Number 14/18/PBI/2012," in tentang kewajiban penyediaan modal minimum bank umum, 2012.

[26] Sihwahjoeni, Pengaruh good corporate governance terhadap ukuran perusahaan dan dampaknya pada manajemen laba. 2015.

[27] and W. N. S. Nurshadrina, T. Edy, "IFRS and earning management practice in Indonesia government bank," in proceeding international conference STIE Mandala Jember, 2017.

[28] V. Anggraita, "Dampakpenerapan PSAK 50/55 (revisi 2006) terhadap manajemen laba di perbankan: Penerapan Mekanisme Corporate Governance, Struktur Kepemilikan dan Kualitas Audit," J. Simp. Nas. Akunt. XV Banjarmasin, 2012.

[29] D. Beatty, A., dan Haris, "The effects of taxes, agency costs, and informationasymmetry on earnings management: acomparison of public and private firms," Rev. Account. Stud., vol. 4, pp. 299-326, 1995.

[30] T. and N. Budisantoso, Bank dan Lembaga Keuangan Lainnya. 2014.

[31] D. et al Muljawan, "Faktor-faktor penentu efisiensi perbankkan indonesia serta dampaknya terhadap perhitungan suku bunga kredit," 2014. 